\title{
The Relationship between Industrial Growth and
}

\section{Labor Force Markets in Turkey}

\author{
Hakan Acaroğlu \\ Department of Economics, Faculty of Economics and Administrative Sciences, \\ Eskisehir Osmangazi University \\ Eskisehir 26480, Turkey
}

Tel: 90-222-239-3750/1750Ｅ-mail: hacaroglu@ ogu.edu.tr

Received: March 10, 2015 Accepted: April 10, 2015 Published: April 12, 2015

doi:10.5296/iss.v3i1.7216 URL: http://dx.doi.org/10.5296/iss.v3i1.7216

An earlier version of this manuscript was presented at 15th Eurasia Business and Economics Society (EBES) Conference, 8-10/January/ 2015 Lisbon, Portugal.

\begin{abstract}
The purpose of the study is to show the relationship between industrial growth and labor participation, unemployment and employment ratios in Turkey in the period 2005-2014. To this end, econometric time series techniques are utilized. The Granger-causality is used for testing the relationship. The data used in the study includes monthly observations from the year 2005 to 2014. The justification of this study is to make observations on the effects of economic policy the Turkish government has been implemented since early 2000s. As a tradeoff, choosing inflation targeting instead of unemployment, Turkey faces unemployment problems especially among the youth that is an important opportunity cost. It is noted that this tradeoff is negatively affecting the growth of the country. This study attemp ts to show the negative effects and further proposes a new economic policy. The other findings also include determination of the direction of the relationship between industrial growth and basic labor force market variables for Turkey.
\end{abstract}

Keywords: economic growth; labor force market; granger-causality 


\section{Introduction}

One of the economic policies to address unemployment is to secure increased growth rate by creating new employment opportunities. This was first introduced in the economic literature by Okun (1962). According to him, higher growth ratios decrease unemployment or in other words, negative growth ratios increase unemployment ratios. However, despite the higher growth rate, unemployment seems to be increasing in Turkey. This study tries to give answers to why this is happening by using advanced econometric techniques.

In literature, there are studies that directly concentrate on the relationship between growth and labor force market. The studies examining the relationship between growth and labor market variables (labor force participation rate, unemployment, employment) for Turkey are Göktaş Yılmaz (2005), Akçorakoğlu (2010), Ceylan \& Yılmaz Şahin (2010), and Kesici (2010).

Phillips (1958) argues that the rate of change of money wage rates in the United Kingdom can be explained by the level of unemployment and the relationship is inversely related. Taking this point of view, Turkey has low inflation rates but high unemployment rates. But we know that there are some indications that Turkey needed a credible disinflation program for continuing its sustainable growth for the years 1980-2002 (Dibooglu \& Kibritcioglu, 2004). Arslan and Ceritoğlu (2013) examined the average quality growth and corresponding inflation bias for the year 2003-2009 in Turkey. They found that the average quality growth is 3.93 percent and the estimated inflation bias is 2.28 percentage points. As global economies are concerned with the importance of inflation targeting, it is stated that inflation targeting regime results in higher output income per capita for industrial and emerging economies (Mollick, Cabral \& Carneiro, 2011). As an emerging economy, Turkey has chosen the inflation targeting policy since the beginning of 2000s. However, this preference brought an important problem that can be called as an opportunity cost of inflation targeting as in form of unemployment, mostly seen among youth.

The Granger-causality is used for testing the relationship. The chosen data contains monthly observations from the year 2005 to 2014. As a tradeoff, choosing inflation targeting instead of decreasing unemployment, Turkey faces with unemployment problems especially among the youth makes an important opportunity cost. It is taught that this tradeoff is negatively affecting the growth of the country.

The methodology and empirical results are shown in the next section. The results that are obtained from statistical tests are shown, and also it explains the negative effects and proposes a new economic policy. In addition, the determination of the direction of the relationship between growth and basic labor force market variables for Turkey is also presented.

\section{Methodology and Empirical Results}

Granger (1969) was the first who showed the existence of causality between variables. In literature the name of the tests are called as Granger-causality tests. These tests are used for obtaining the existence of causality considering two variables. Two step procedure is applied 
for determining the causality relationship between these variables. In the first step a variable is regressed with its past values. In the second step a variable, additionally to the first step, is regressed with the past values of another variable. By comparing these two regressions if the obtained prediction error is smaller than the first regression this implies that the added variable is the Granger-cause of the first variable. The condition for applying Granger-causality test is the stationary of variables. Therefore, unit root tests are used for determining the stationary of variables. There are some different approaches for unit root tests. One of them is proposed by Phillips and Perron (1988) which we also preferred in this study.

\subsection{Methodology}

In the methodology of this study, as Gross Domestic Product (GDP), seasonal and calendar adjusted industrial production index $(2010=100)$ time series is used. Testing Granger-causality between GDP and Labor Market variables, two bidirectional models are determined first. The variables that represented labor force market are labor force, employment, unemployment, and youth unemployment. While the labor force variable is represented by labor force participation rate, the employment variable and unemployment variable are represented by employment rate and unemployment rate, respectively in this study. Moreover, the last variable is youth unemployment as represented by unemployment rate in youth population. One of the se variables in the Granger-causality test is for GDP and the other one is for labor force market. We can show the steps for Granger-causality tests as indicated in the equations below. (Note 1):

$$
\begin{aligned}
& \Delta Y_{t}=\alpha_{11}+\sum_{i=1}^{L_{11}} \beta_{11 i} \Delta Y_{t-i}+\varepsilon_{11 \mathrm{t}} \\
& \Delta Y_{t}=\alpha_{12}+\sum_{i=1}^{L_{11}} \beta_{11 i} \Delta Y_{t-i}+\sum_{j=1}^{L_{12}} \beta_{12 j} \Delta X_{t-j}+\varepsilon_{12 \mathrm{t}} \\
& \Delta X_{t}=\alpha_{21}+\sum_{i=1}^{L_{21}} \beta_{21 i} \Delta X_{t-i}+\varepsilon_{21 \mathrm{t}} \\
& \Delta X_{t}=\alpha_{22}+\sum_{i=1}^{L_{21}} \beta_{21 i} \Delta X_{t-i}+\sum_{j=1}^{L_{22}} \beta_{22 j} \Delta Y_{t-j}+\varepsilon_{22 \mathrm{t}}
\end{aligned}
$$

While $\Delta$ is the difference symbol, $Y_{t}$ represents GDP and $X_{t}$ represents one of the labor force variable. On the top of sum operator, $\mathrm{L}$ indicates the number of lags, $\varepsilon_{\mathrm{t}}$ is for error component, $\alpha$ and $\beta$ are for estimation parameters. Equations can be classified into two groups as; restricted and unrestricted; Equation (1), Equation (3) and Equation(2), Equation(4) respectively. On the other hand, while Equation (1) and Equation (2) are evaluated together for if labor force is Granger-cause of GDP. Reversely, Equation (3) and Equation (4) are evaluated together for if GDP is Granger-cause of labor force. This is done by considering the significance of past lags of variables. If they are significant, it means that they are Granger-cause of the dependent 
variable (Yang, 2000). There is one possibility that the coefficient of lagged variables can be zero, so this is controlled by checking the $\mathrm{F}$ tests for pairs of equations. Before using Granger-causality tests, co-integration between variables should be tested and when two variables are co-integrated then another test that is proposed by Engle and Granger (1987) should be applied. The name of this test is Error-correciton Model (see for the details of procedure... (Yang, 2000, p.311)).

The wright lagging numbers are important to calculate the causality relationships. Hsiao's (1981) study, presents selecting wright lagging number by using Final Prediction Error (FPE) that is taken from Akaike (1969). This study uses the same procedure as it is also shown in Yang (2000). Once the optimal lags are chosen by the help of smallest FPE values, the causality relationship can be determined. The smallest FPE among Equation (1) and Equation (2) is used for the one direction of causality, the other smallest FPE among Equation (3) and Equation (4) is used for the other direction of causality between GDP and labor force market variables.

\subsection{Data and Variable Definitions}

In order to investigate whether there is a causal relationship between Industrial Growth and Labor Force Market in Turkey, monthly data covering the period 2005-2014 (for the year 2014, only the January data is included, since the other months are not available) are used. The growth variable is represented by seasonal and calendar adjusted industrial production index from Turkish Statistical Institute (TurkStat). The base year of this index is 2010, and it includes the Turkey's total ind ustry. The variables that represent the Labor Force Market are labor force, employment, and unemployment. All the data, from TurkStat, are seasonally and calendar adjusted labor force indicators. In addition to these basic labor force indicators, the data also include the unemployment among youth population. This data is also obtained from TurkStat.

Consequently, GDP is the total industry index calculated with the 2010 base year. LABORFORCE is the employment participation rate and abbreviated by LPR in the equations and tables. UNEMPLOMENT is the unemployment rate and abbreviated by UR in the equations and tables. EMPLOYMENT is the employment rate and abbreviated by ER in the equations and tables. YOUTH UNEMPLOYMENT is the unemployment rate among the youth and abbreviated by YUR in the equations and tables.

\subsection{Turkish Reality Facts about Growth and Labor Force Market with Graphs: Turkish Reality about What is Happening in the Economy}

Figure 1 shows the three different GDP per capita from an outer source between 2003 and 2012 for Turkey. In each GDP per capita the increase in trend can be noticed. The only event that breaks this increase is the global financial crisis in 2008. Besides this, we can be sure about the increase in GDP per capita levels for the last decade in Turkey. 


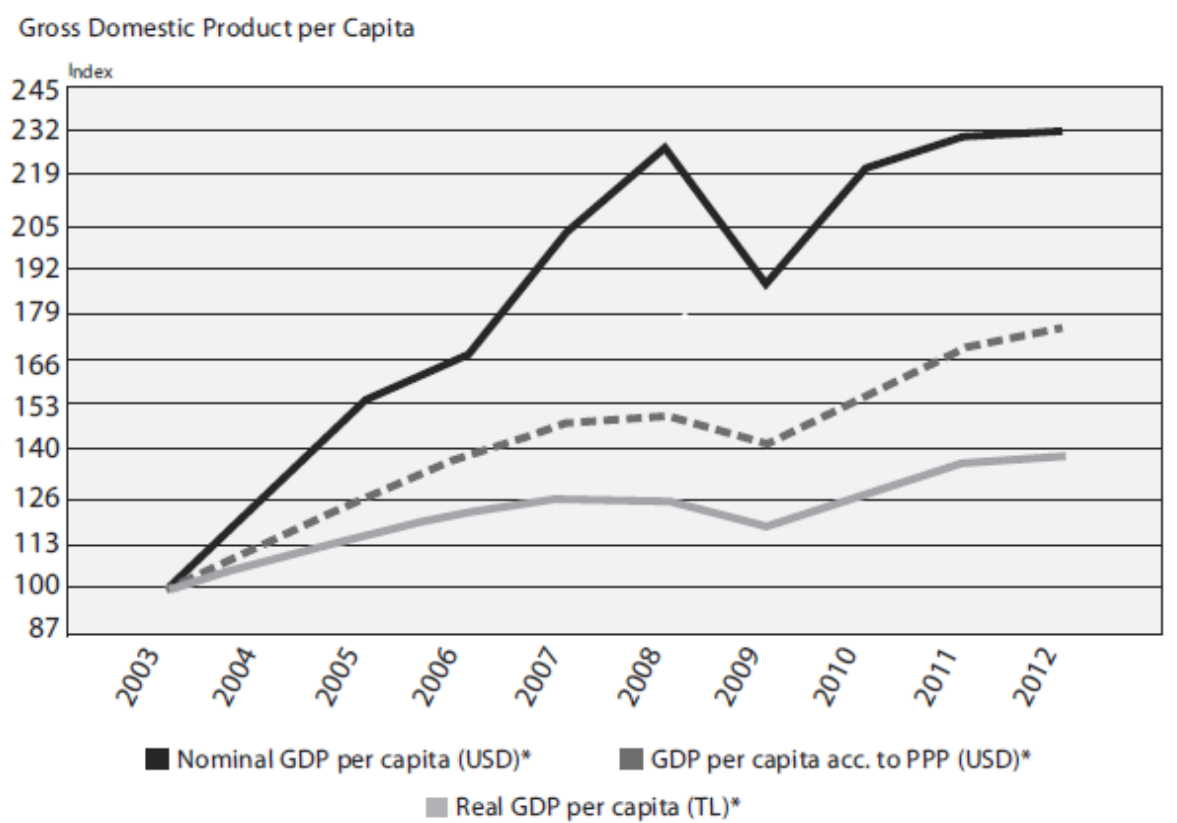

Figure 1. Three different GDP per capita by index 2003=100, since 2003 for Turkey Source: http://goo.gl/DbWMe; Kibritçioğlu, 2013, p.10

Figure 2 shows the monthly seasonal and calendar adjusted ind ustrial production index $(2010=$ 100) from an inner source, for the years between 2005 and 2014 in Turkey. We assume this index as industrial growth of a country. Inner source means that we use this data also for our statistical calculations in the further sections of this study. The data fromouter source (Figure-1) and inner source (our data) are very close to each other although they are calculated by different approaches. The increase trend is both seen in Figure-1 and Figure-2 except for the 2008 global financial crisis.

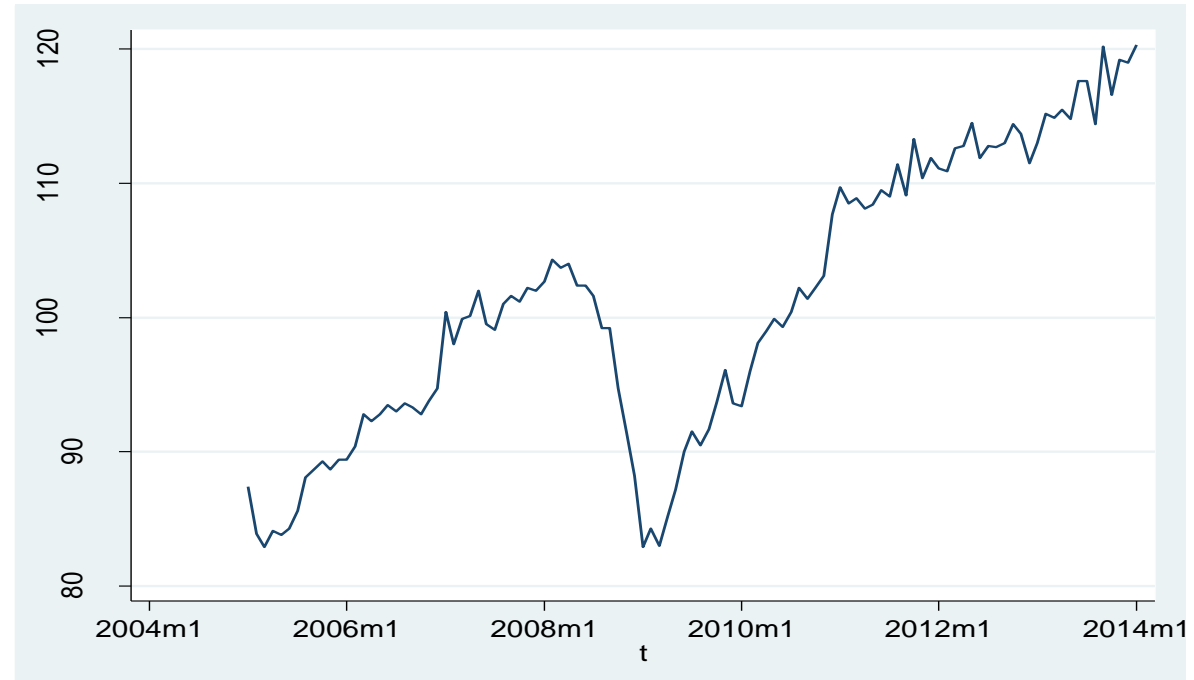




\section{Macrothink}

Figure 2. Growth in Turkey by the total industry index calculated with the 2010 base year Source: TurkStat, Industrial production index, August 2014

While Figure 3 shows the relationship between industrial growth and labor force participation rate, Figure 4 shows the relationship between industrial growth and employment rate for the years between 2005 and 2014 in Turkey. In both figures, until 2009 the relationship is ambiguous but after this year it shows a similar behavior. On the other hand, statistical tests will give us the exact situation between two variables. That's why we need to apply some econometric techniques to see more clearly the direction of the relationship that indicated in Figures.

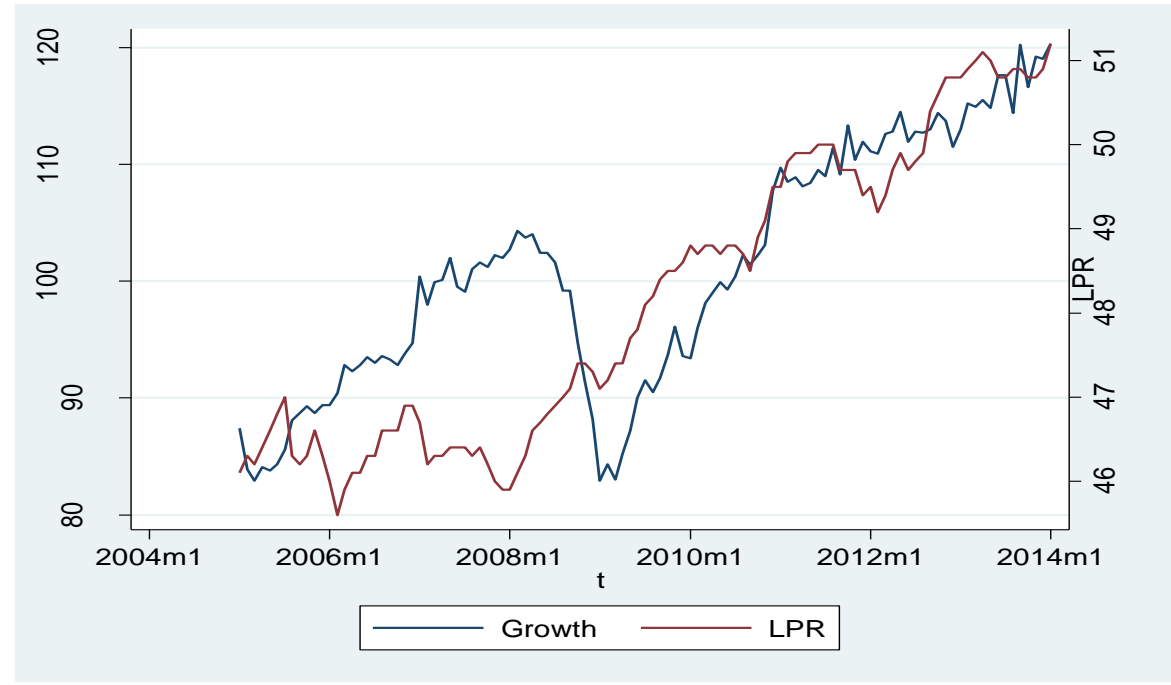

Figure 3. Growth and Labor Force Participation Rate in Turkey

Source: TurkStat, The results of Household Labor Force Survey

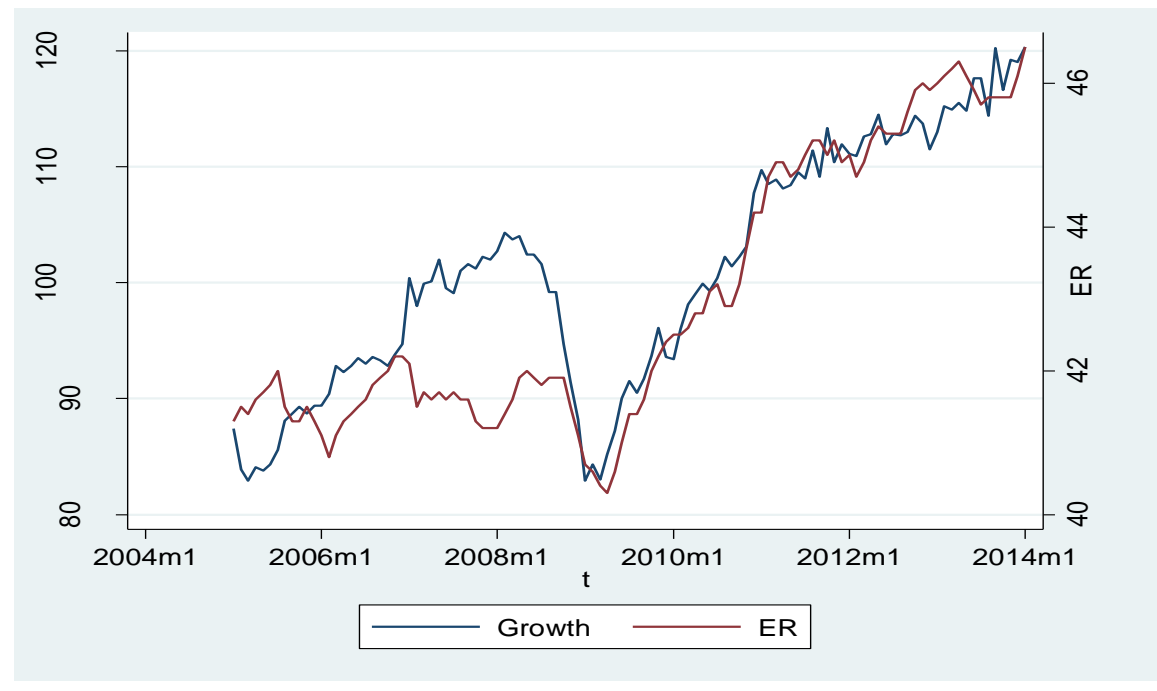

Figure 4. Growth and Employment Rate in Turkey

Source: TurkStat, The results of Household Labor Force Survey 


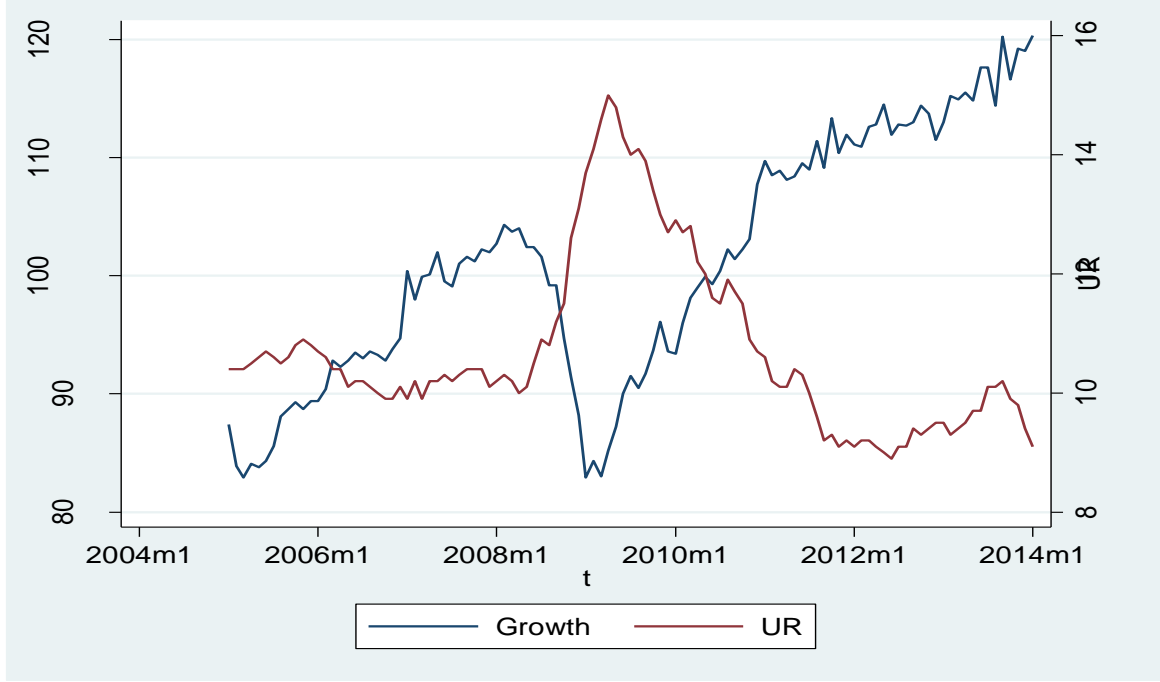

Figure 5. Growth and Unemployment Rate in Turkey

Source: TurkStat, The results of Household Labor Force Survey

While Figure 5 shows the relationship between industrial growth and unemployment rate, Figure 6 shows the relationship between industrial growth and youth unemployment rate for the years between 2005 and 2014 in Turkey. In both figures, the relationship seems opposite each other. On the other hand, when the youth unemployment is concerned, the rates are almost doubled. Therefore we understand that Turkey faces a serious unemployment problem mostly among youth.

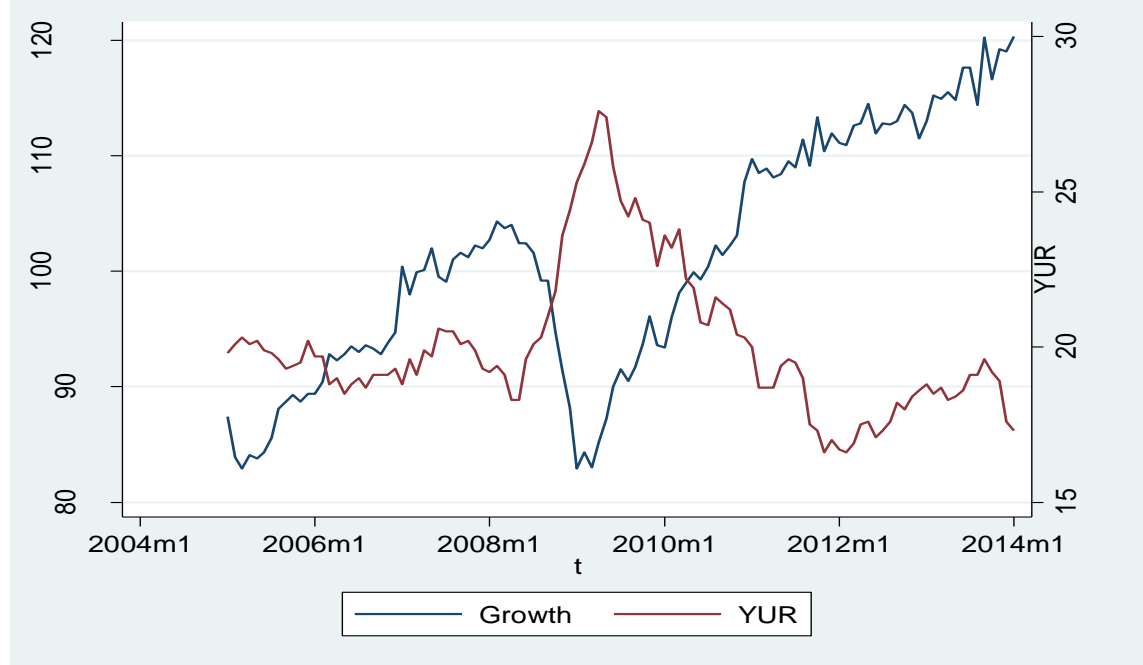

Figure 6. Growth and Youth Unemployment Rate in Turkey

Source: TurkStat, The results of Household Labor Force Survey 


\subsection{Empirical Results}

The test results that are obtained from unit-root and co-integration tests are shown in Table-1 and Table-2. Table-1 shows the unit-root tests in monthly period between 2005-2014 for the GDP, LABORFORCE, UNEMPLOYMENT, EMPLOYMENT and YOUTHEMPLOYMENT variables. This study uses Phillips-Perron test for unit-roots and stationary. As it is also seen in Table-1's first column, all variables' Phillips-Perron test value is greater than the -4.037 (critical value) at the level of $\% 1$ significance. This finding indicates that the variables are not stationary. On the other hand, the non-stationary condition can be rejected when all the variables of series converted to their first difference at the $\% 1$ significance level. Therefore, Granger-causality models for the 2005-2014 years can be predicted with their first difference or in other words, the Granger-causality models can be estimated with first difference data.

Table 1. Unit-root tests, 2005-2014

\begin{tabular}{lcc}
\hline Variables & Level & $\begin{array}{c}\text { First difference } \\
\text { Phillips-Perrron value }\end{array}$ \\
\hline GDP & -1.902 & $-11.680^{*}$ \\
LABORFORCE & -2.324 & $-8.668^{*}$ \\
UNEMPLOYMENT & -1.395 & $-6.948^{*}$ \\
EMPLOYMENT & -1.723 & $-7.354^{*}$ \\
YOUTHEMPLOYMENT & -1.633 & $-8.859^{*}$ \\
\hline
\end{tabular}

* The critical value of the Phillips-Perron statistic at the ***\%10 level: -3.149 , at the **\%5 level:-3.449, at the $* \% 1$ level: -4.037 .

If GDP and LABORFORCE, UNEMPLOYMENT, EMPLOYMENT and YOUTH UNEMPLOYMENT variables satisfy all the stationary conditions then Granger's causality test can be applied. In some exceptional cases there can be needed for the application of some modelling types. One of them is error-correction modelling. This modelling is needed where there exist co-integration in the series. As it is shown in Table-2; the co-integration tests for GDP and LABORFORCE variables are reported. Since the Phillips-perron results satisfy the condition of the series are not co-integrated (Phillips-perron $t$ values $>-3.37$ for $\% 5$ significance level), therefore the Granger's causality test can be applied by using Equation (1)-(4) (Note 2).

Table 2. Co-integration tests

\begin{tabular}{lc}
\hline Co-integration regressions & Series: $2005-2014$ (monthly) \\
\hline GDP-LABORFORCE & -1.76 \\
GDP-UNEMPLOYMENT & -1.65 \\
GDP-EMPLOYMENT & -2.36 \\
GDP-YOUTHUNEMPLOYMENT & -1.53 \\
\hline
\end{tabular}

** The critical value of the statistic at the at the $\% 5$ significance level:- 3.37 , (the critical value of $\mathrm{ADF}(1)$ for lower than 200 observations (see.. Sjö, 2008, p.23)). 


\section{Macrothink}

Issues in Social Science

ISSN 2329-521X

2015, Vol. 3, No. 1

\subsection{Granger's Causality Test Results}

The time series that are used in this study are not stationary. For this reason all the series are transformed into stationary level. This level is the first difference. Optimal lags are chosen by FPE criterion. The test results are shown in Table-3a, according to the monthly calculated data that consist 2005-2014 period, for the equation of GDP-LPR, since $5.9 \mathrm{e}^{-31}>2.4 \mathrm{e}^{-32}$ the hypothesis of LPR is Granger-cause of GDP is accepted. For the other equation (LPR), since $8.0 \mathrm{e}^{-71}<1.6 \mathrm{e}^{-70}$, the hypothesis of GDP is Granger-cause of LPR cannot be accepted. In addition to this, as also indicated in the last column of Table-3a, GDP-LPR equation is statistically significant so that there is uni-directional causality between GDP-LPR from GDP to LPR.

As it is shown in Table-3b, according to the monthly calculated data that consist 2005-2014 period, for the equation of GDP-UR, since $5.9 \mathrm{e}^{-31}>3.1 \mathrm{e}^{-32}$, the hypothesis of UR is Granger-cause of GDP can be accepted. For the inverse equation UR-GDP, since $1.7 \mathrm{e}^{-68}<1.2$ $\mathrm{e}^{-34}$, the hypothes is of GDP is Granger-cause of UR cannot be accepted. In addition to this, as also indicated in the last column of Table-3b, GDP-UR equation is statistically significant at \%5 significance level and UR-GDP equation is also statistically significant at \%1 significance level. This means that there is a bi-directional causality between GDP-UR both from GDP to UR and UR to GDP.

As it is shown in Table-3c, according to the monthly calculated data that consist 2005-2014 period, for the equation of GDP-ER, since $5.9 \mathrm{e}^{-31}>2.6 \mathrm{e}^{-32}$, the hypothesis of ER is Granger-cause of GDP can be accepted. On the other hand, for the equation of ER-GDP, since1.2 $\mathrm{e}^{-34}<4.2 \mathrm{e}^{-34}$, the hypothesis of GDP is Granger-cause of ER cannot be accepted. In addition, as also indicated in the last column of Table-3c, GDP-ER equation is statistically significant at $\% 5$ significance level and UR-GDP equation is also statistically significant at $\% 1$ significance level so that there is a bi-directional causality between GDP-ER both from GDP to ER and ER to GDP.

As it is shown in Table 3d, according to the monthly calculated data that consist 2005-2014 period, for the equation of GDP-YUR, since $5.9 \mathrm{e}^{-31}>1.8 \mathrm{e}^{-31}$, the hypothesis of YUR is Granger-cause of GDP can be accepted. Conversely, for the equation of YUR-GDP, since 1.7 $\mathrm{e}^{-64}<4.4 \mathrm{e}^{-64}$, the hypothesis of GDP is Granger-cause of YUR cannot be accepted. In addition to this, as also indicated in the last column of Table-3d, GDP-YUR equation is statistically significant at $\% 5$ significance level but YUR-GDP equation is not statistically significant so that there is a unidirectional causality between GDP-YUR, only from YUR to GDP but not from GDP to YUR.

Table 3. Granger's causality tests between GDP $^{1}$ and LABOR FORCE MARKET VARIABLES $^{2}$ with 2005-2014 period monthly data

\begin{tabular}{lll}
\hline a)Regressions: $2005-2014$ period monthly data for GDP-LPR test & FPE & F-value \\
\hline$\Delta G D P_{t}=\alpha_{11}+\sum_{i=1}^{1} \beta_{11 i} \Delta G D P_{t-i}+\varepsilon_{11 \mathrm{t}}$ & $5.9 \mathrm{e}^{-31}$ & 1.15
\end{tabular}




$$
\begin{array}{ll}
\Delta G D P_{t}=\alpha_{12}+\sum_{i=1}^{1} \beta_{11 i} \Delta G D P_{t-i}+\sum_{j=1}^{1} \beta_{12 j} \Delta L P R_{t-j}+\varepsilon_{12 \mathrm{t}} & 2.4 \mathrm{e}^{-32} \\
\Delta L P R_{t}=\alpha_{21}+\sum_{i=1}^{1} \beta_{21 i} \Delta L P R_{t-i}+\varepsilon_{21 \mathrm{t}} & 8.0 \mathrm{e}^{-71}
\end{array}
$$

$\Delta L P R_{t}=\alpha_{22}+\sum_{i=1}^{1} \beta_{21 i} \Delta L P R_{t-i}+\sum_{j=1}^{2} \beta_{22 j} \Delta G D P_{t-j}+\varepsilon_{22 \mathrm{t}} \quad 1.6 \mathrm{e}^{-70}$

b) Regressions: 2005-2014 period monthly data for GDP-UR test $\quad$ FPE $\quad$ F-value

$$
\Delta G D P_{t}=\alpha_{11}+\sum_{i=1}^{1} \beta_{11 i} \Delta G D P_{t-i}+\varepsilon_{11 \mathrm{t}} \quad 5.9 \mathrm{e}^{-31}
$$

$\Delta G D P_{t}=\alpha_{12}+\sum_{i=1}^{1} \beta_{11 i} \Delta G D P_{t-i}+\sum_{j=1}^{1} \beta_{12 j} \Delta U R_{t-j}+\varepsilon_{12 \mathrm{t}}$

$$
\Delta U R_{t}=\alpha_{21}+\sum_{i=1}^{1} \beta_{21 i} \Delta U R_{t-i}+\varepsilon_{21 \mathrm{t}} \quad 1.7 \mathrm{e}^{-68}
$$

$$
\Delta U R_{t}=\alpha_{22}+\sum_{i=1}^{1} \beta_{21 i} \Delta U R_{t-i}+\sum_{j=1}^{1} \beta_{22 j} \Delta G D P_{t-j}+\varepsilon_{22 \mathrm{t}} \quad 1.2 \mathrm{e}^{-34}
$$

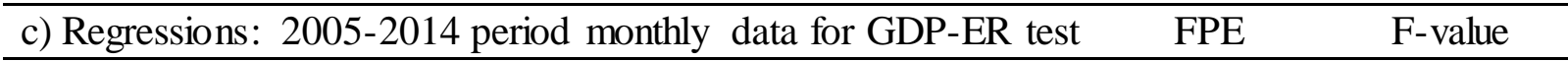

$$
\Delta G D P_{t}=\alpha_{11}+\sum_{i=1}^{1} \beta_{11 i} \Delta G D P_{t-i}+\varepsilon_{11 \mathrm{t}} \quad 5.9 \mathrm{e}^{-31}
$$

$$
\Delta G D P_{t}=\alpha_{12}+\sum_{i=1}^{1} \beta_{11 i} \Delta G D P_{t-i}+\sum_{j=1}^{1} \beta_{12 j} \Delta E R_{t-j}+\varepsilon_{12 \mathrm{t}} \quad 2.6 \mathrm{e}^{-32}
$$

$$
\Delta E R_{t}=\alpha_{21}+\sum_{i=1}^{1} \beta_{21 i} \Delta E R_{t-i}+\varepsilon_{21 \mathrm{t}} \quad 1.2 \mathrm{e}^{-34}
$$$$
\Delta E R_{t}=\alpha_{22}+\sum_{i=1}^{1} \beta_{21 i} \Delta E R_{t-i}+\sum_{j=1}^{2} \beta_{22 j} \Delta G D P_{t-j}+\varepsilon_{22 \mathrm{t}} \quad 4.2 \mathrm{e}^{-34}
$$

\begin{tabular}{llll}
\hline d) Regressions: $2005-2014$ period monthly data for GDP-YUR test & FPE & F-value
\end{tabular}

$$
\begin{array}{ll}
\Delta G D P_{t}=\alpha_{11}+\sum_{i=1}^{1} \beta_{11 i} \Delta G D P_{t-i}+\varepsilon_{11 \mathrm{t}} & 5.9 \mathrm{e}^{-31} \\
\Delta G D P_{t}=\alpha_{12}+\sum_{i=1}^{1} \beta_{11 i} \Delta G D P_{t-i}+\sum_{j=1}^{3} \beta_{12 j} \Delta Y U R_{t-j}+\varepsilon_{12 \mathrm{t}} & 1.8 \mathrm{e}^{-31}
\end{array}
$$




$$
\begin{array}{ll}
\Delta Y U R_{t}=\alpha_{21}+\sum_{i=1}^{1} \beta_{21 i} \Delta Y U R_{t-i}+\varepsilon_{21 \mathrm{t}} & 1.7 \mathrm{e}^{-64} \\
\Delta Y U R_{t}=\alpha_{22}+\sum_{i=1}^{1} \beta_{21 i} \Delta Y U R_{t-i}+\sum_{j=1}^{3} \beta_{22 j} \Delta G D P_{t-j}+\varepsilon_{22 \mathrm{t}} & 4.4 \mathrm{e}^{-64}
\end{array}
$$

${ }^{1}$ GDP: Gross Domestic Product, ${ }^{2}$ LPR: Labor Force Participation Rate, ${ }^{2}$ UR: Unemployment Rate, ${ }^{2}$ ER: Employment Rate, ${ }^{2}$ YUR: Young Unemployment Rate). Note: 1-FPE (Final Prediction Error) Akaike (1969) presents final prediction error. 2- *\%1,**\%5, ***\%10 presents the significance levels.

\subsection{Discussion of the Empirical Results}

For the first case; $\quad$ LPR $\rightarrow$ GDP but it is not significant

$$
\text { GDP } \rightarrow \text { LPR and it is significant }
$$

The result is that there is a causal relations hip between LPR and GDP from LPR to GDP but the relation is not significant. On the other hand, there is no causal relationship between GDP and LPR from GDP to LPR. So the relationship between LPR and GDP is weak.

For the second case; UR $\rightarrow$ GDP and it is significant

$$
\mathrm{GDP} \rightarrow / \mathrm{UR} \quad \text { and it is significant }
$$

The result is that there is a causal relationship between UR and GDP from UR to GDP and the relation is significant. On the other hand, there is no causal relationship between GDP and UR from GDP to UR. So, the relationship between UR and GDP is unidirectional from UR to GDP.

For the third case; $\quad \mathrm{ER} \rightarrow \mathrm{GDP} \quad$ and it is significant

$$
\text { GDP } \rightarrow / \text { ER } \quad \text { and it is significant }
$$

The result is that there is a causal relationship between ER and GDP from ER to GDP and the relation is significant. On the other hand, there is no causal relationship between GDP and ER from GDP to ER. So, the relationship between ER and GDP is unidirectional from ER to GDP.

For the fourth case; YUR $\rightarrow$ GDP and it is significant

$$
\text { GDP } \rightarrow \text { YUR } \quad \text { but it is not significant }
$$

The result indicates that there is a causal relationship between YUR and GDP from YUR to GDP and the relationship is significant. On the other hand, there is no causal relationship between GDP and YUR from GDP to YUR. So, the relationship between YUR and GDP is unidirectional from YUR to GDP.

In this study, the causal relationships between Industrial Growth and Labor Force Market are investigated based on the monthly calculated data that consists of 2005-2014 period in Turkey. If there exists a causal relationship are shown from optimal lag values of difference series are presented at Table-3. Results indicate that in the period 2005-2014, LPR, UR, ER and YUR are 


\section{Macrothink}

Issues in Social Science

ISSN 2329-521X

2015, Vol. 3, No. 1

Granger-cause of GDP. However, GDP is not Granger-cause of the Labor force variables so the general characteristics of the relationship are unidirectional from Labor force variables to GDP. The causality between GDP and LPR exist from LPR to GDP, but it is not significant. Therefore the relationship between GDP and LPR is weak. Since LPR is the sum of ER and UR, the effects of ER and UR are close to each other, however; the positive effect of ER is smaller than the negative effect of UR (ER<UR) on GDP according to the significance degree of $F$ values in Turkey.

\section{Conclusion}

This study uses monthly time series data for 2005-2014, and considers Turkey. Granger-causality econometric techniques are used for to determine the causality and also its direction between GDP and labor force market variables. In related to these analyses, the causal relationship between GDP and the basic determinants of labor force market is investigated, including participation to labor force, employment rate, unemployment rate, and unemployment rate among youth. Unidirectional causality relationship between GDP and Labor force variable from Labor force variables to GDP is found. Further, we find that the relationship between GDP and LPR is weak. However the positive effect of ER is smaller than the negative effect of UR on GDP (ER<UR).

The most important finding from the results is that in 2005-2014 periods, the increase or decrease in GDP does not affect all the labor force variables in Turkey. Therefore Okun Law is not satisfied in whole; higher growth ratios do not decrease unemployment. Conversely, the positive growth ratios increase unemployment ratios for Turkey.

As a conclusion, it can be said that the finding regarding Okun Law is one of the greatest disadvantages of currently applied inflation targeting policy for Turkey that has a higher rate of youth population in its population structure. The increase in industrial growth does not result a significant increase in youth employment. This situation seems a potential threat for healthy and stable economy in the long run.

\section{References}

Akaike, H., (1969). Fitting autoregressive models for prediction. Ann. Inst. Stat. Math., 21, 243-247.

Akçorakoğlu, A. (2010). Employment, Economic Growth and Labor Market Performance: The Case of Turkey. Ekonomik Yaklaşım. Cilt:21, Sayı:, 77, 101-114.

Arslan, Y., \& Ceritoğlu, E. (2011). Quality Growth versus Inflation in Turkey. Central Bank Republic of Turkey. Working Paper No:11/21.

Ceylan, S., \& Y1lmaz Şahin, B. (2010). Asymmetry in the Relationship between Unemployment and Economic Growth. Doğuş Üniversitesi Dergisi, 11(2), 157-165.

Dibooglu, S., \& Kibritcioglu, A. (2004). Inflation, Output Growth, and Stabilizationin Turkey, 1980-2002. Journal of Economics and Business, 56, 43-61. 
Engle, R. F., \& ve Granger, C. W. J. (1987). Co-Integration and Error Correction: Representation, Estimation, and Testing. Econometrica, 55(2), 251-276.

Göktaş Yı1maz, Ö. (2005). Türkiye Ekonomisinde Büyüme İle İşsizlik Oranları Arasındaki Nedensellik İlişkisi, Ekonometri ve İstatistik,. İstanbul Üniversitesi İktisat Fakültesi Ekonometri ve Istatistik Dergisi, 2, 11-29.

Granger, C. W. J. (1969). Investigating causal relation by econometric and cross-sectional method. Econometrica, 37, 424-438.

Hsiao, C. (1981). Autoregressive modeling and money income causality detection. J. Mon. Econ., 7, 85-106.

Kesici, M. R. (2010). In High Growth Phase of Turkey Economy Employment and Unemployment. “Is, Guc” Industrial Relations and Human Resources Journal, 2(3), 7-26.

Kibritçioğlu, A. (2013). How much has Turkey's GDP grown between 2002 and 2012? MPRA Paper, No. 56639. http://mpra.ub.uni-muenchen.de/56639/

Mollick, A. V., Cabral, R., \& Carneiro, F. G. (2011). Does Inflation Targeting Matter for Output Growth? Evidence from Industrial and Emerging Economies. Journal of Policy Modeling. 33, 537-551.

Okun, A. M. (1962). Potential GNP: It's Measurement and Significance American Statistical Association. Proceedings of the Business and Economics Statistics Section (pp. 98-104).

Phillips, A. W. (1958). The Relation Between Unemploynment and the Rate of Change of Money Wage Rates in the United Kingdom, 1861-1957. Economica, New Series, 25(100), 283-299.

Phillips, P. C. B., \& ve Perron, P. (1988). Testing for a unit root in time series regression, Biometrika, 75, 335-346.

Sjö, B. (2008). Testing for Unit Roots and Cointegration. [Online] Available: https://www.iei.liu.se/nek/ekonometrisk-teori-7-5-hp-730a07/labbar/1.233753/dfdistab7b.pdf

Yang, H. -Y., (2000). A note on the causal relationship between energy and GDP in Taiwan. Energy Economics, 22, 309-317.

\section{Notes}

Note 1. It is helped for this study to testing the Granger-causality between two variables from Granger (1969, p.431); simple causality model that is existed by two stationary time series with zero average. However, the variables used in Granger's model is represented as only by instantaneous and lag time values but not as difference model. It is possible to express these 


\section{Macrothink

models by difference variables at the same time. It is possible to see this approach in Yang (2000) by taking differences both side of equation. Yang's study which is about the causality relationship between energy and GDP for Taiwan is also followed in setting up the methodology for this study.

Note 2. In the regression of GDP-LABORFORCE, for the t-critical values at the lag values of , takes -1.76 for the series. This $t$ values are bigger than co-integration regression value -3.37 at the $5 \%$ significance level. In this situation, the $\mathrm{H} 0=0$ hypothesis that is there is no co-integration $(t>t c)$ is not rejected. In the series, since the case of $t>3.37$ is satisfied the H0 hypothesis; least square residuals are non-stationary are not rejected; or in other words, residuals are not stationary. In this situation the GDP and LABORFORCE variables are not co-integrated for series. The same case is repeated also for UNEMPLOYMENT, EMPLOYMENT and YOUTHUNEMPLOYMENT variables. According to this; for UNEMPLOYMENT, EMPLOYMENT and YOUTHUNEMPLOYMENT variables are not co-integrated for series is valid. 